\title{
F-16438s, Novel Binding Inhibitors of CD44 and Hyaluronic Acid
}

\author{
I. Establishment of an Assay Method and Biological Activity \\ Hosami Harada, Tomoko Nakata, Yuki Hirota-Takahata, Isshin Tanaka, \\ Mutsuo Nakajima, Masaaki Takahashi
}

Received: August 11, 2006 / Accepted: November 14, 2006

(C) Japan Antibiotics Research Association

\begin{abstract}
In an attempt to obtain inhibitors of hyaluronic acid (HA) binding to its receptor, CD44, we established an efficient assay method to detect and quantify binding using fluorescein-labeled HA and HEK293 cells stably expressing CD44. As a result of the screening of culture broths of microorganisms, we found fungus strain Gloeoporus dichrous SANK 30502 produced inhibitory activity in this new assay. Five compounds, F-16438 A, B, $\mathrm{E}, \mathrm{F}$ and $\mathrm{G}$, were isolated from the fermentation broths, and their $\mathrm{IC}_{50}$ values were determined to be 10.3, 13.5, 27.3, 12.0 and $13.0 \mu \mathrm{M}$, respectively. F-16438 A, B, E, F and G are the first reported inhibitors of binding HA to CD44. F-16438 A, B, E and F have novel structures.
\end{abstract}

Keywords hyaluronic acid, CD44, binding inhibitor, screening method, F-16438

\section{Introduction}

Hyaluronic acid (HA) is a high-molecular-weight, straight-chain glycosaminoglycan (GAG) composed of repeating alternating units of glucuronic acid and $\mathrm{N}$-acetylglucosamine. Despite its structural simplicity, HA has a great number of diverse functions. It has been shown that HA participates in embryonic development and morphogenesis $[1,2]$, wound healing $[3,4]$, inflammation
$[5,6]$, and tumor progression and invasion [7, 8]. In addition, since the molecular domain of HA encompasses a large volume of water, HA also functions as a lubricant and as a shock absorber, and acts as an important structural molecule in tissues such as the vitreous of the eye [9] and synovial joint fluid [10]. In fact, the concentration and average molecular weight of HA in the joint fluids are reduced in diseases such as osteoarthritis and rheumatoid arthritis [11, 12].

The transmembrane glycoprotein CD44 is a major HA cell surface receptor expressed abundantly on many cell types, including macrophages, lymphocytes, fibroblasts, epithelial cells, chondrocytes and several tumor cells [13 18]. Using a variety of experimental models, CD44 has been shown to mediate cell-cell and cell-ECM interactions [19 21], co-stimulate lymphocyte activation $[22,23]$, and promote growth and metastasis of some tumors [24, 25]. In highly invasive breast cancer cell lines, turnover of $\mathrm{HA}$ and expression of CD44 are upregulated [26]. By treatment with catabolic stimulators like interleukin-1 alpha and fibronectin fragment, CD44 is upregulated in chondrocytes [27]. It has also been shown that HA is taken up by these cells for degradation through the HA receptor [28 30]. Based on all those observations, we hypothesized that inhibition of HA binding to the CD44 receptor will inhibit CD44 functions and/or turnover of HA, and may therefore be of therapeutic value in
M. Takahashi (Corresponding author), H. Harada, T. Nakata: Lead Discovery Research Laboratories, Sankyo Co., Ltd., 1-2-58 Hiromachi, Shinagawa-ku, Tokyo 140-8710, Japan, E-mail: mtakah@sankyo.co.jp
Y. Hirota-Takahata, I. Tanaka, M. Nakajima: Core Technology Research Laboratories, Sankyo Co., Ltd., 1-2-58 Hiromachi, Shinagawa-ku, Tokyo 140-8710, Japan 
the treatment of various diseases including cancer, osteoarthritis and rheumatoid arthritis.

In order to obtain agents having inhibitory activity of the interaction between $\mathrm{HA}$ and CD44, we analyzed the function of CD44 expressed exogenously in HEK293 cells and developed an efficient assay method to detect binding of HA to CD44 on HEK293 cells. In the course of a screening program, fungus strain Gloeoporus dichrous SANK 30502 was discovered to produce novel CD44-HA binding inhibitors, which were coded as F-16438s. In this paper, we describe the establishment of an assay method and the biological activities of these inhibitors. The fermentation, isolation and structural elucidation as well as the physico-chemical properties of these compounds are reported elsewhere [31].

\section{Materials and Methods}

\section{Establishment of HEK293 Cells Stably Expressing Human CD44}

HEK239 (293) cells were maintained in a humidified incubator at $37^{\circ} \mathrm{C}$ in $5 \% \mathrm{CO}_{2}$ in Dulbecco's Modified Eagle's Medium (DMEM) supplemented with 10\% fetal calf serum, $100 \mathrm{units} / \mathrm{ml}$ penicillin and $100 \mu \mathrm{g} / \mathrm{ml}$ streptomycin. The cDNA of human CD44 was amplified by polymerase chain reaction (PCR) using a Human Lymph Node cDNA Library (Takara) as a template, and inserted into the expression vector pRK5. HEK293 cells were cotransfected with pRK5/CD44 and pSV2neo by a calcium phosphate transfection method. A cell lineage expressing CD44 was selected using $500 \mu \mathrm{g} / \mathrm{m}$ of Geneticin (GIBCO) and was named CD44/293.

\section{Western Blotting}

Cells $\left(5 \times 10^{6}\right)$ were washed and collected with $1 \mathrm{ml}$ of phosphate-buffered saline (PBS). After centrifugation at 3,000 rpm for 10 minutes, the supernatant was removed and $500 \mu \mathrm{l}$ of lysis buffer (Bio-Rad) was added to the cells. The cells were lysed with sonication. The lysate was incubated at $95^{\circ} \mathrm{C}$ for 5 minutes and then subjected to sodium dodecyl sulfate polyacrylamide gel electrophoresis (SDS-PAGE). The proteins were transferred to PVDF membranes and immunoblotted with specific antibodies for human CD44 (V6034, Biomeda), after which they were detected using an ECL Plus Western Blotting Detection System (Amersham Biosciences).

\section{Preparation of Fluorescein-labeled Hyaluronic Acid}

Fluorescein-hyaluronic acid (fl-HA) was prepared as described by de Belder and Wik [32] with a slight modification. Briefly, $50 \mathrm{mg}$ of hyaluronic acid (800 $1200 \mathrm{kDa}$, Seikagaku Kogyo) was dissolved in $40 \mathrm{ml}$ of water, and mixed with $20 \mathrm{ml}$ of DMSO. Fluorescein-amine, isotype I ( $25 \mathrm{mg}$, Aldrich) in DMSO $(0.5 \mathrm{ml})$ containing acetaldehyde $(25 \mu \mathrm{l}$, Fluka) and cyclohexyl isocyanide (25 $\mu 1$, Fluka) was added into the mixture. The mixture was incubated at $25^{\circ} \mathrm{C}$ for 5 hours, and then poured into $240 \mathrm{ml}$ of ethanol saturated with $\mathrm{NaCl}$. The precipitated fl-HA was collected by centrifugation at $1000 \mathrm{~g}$ and air-dried in a chemical hood. The fl-HA was then dissolved in water and re-precipitated using $\mathrm{NaCl}$-saturated ethanol 2 times. The fl-HA was further purified by exhaustive dialysis against distilled water. An aliquot of fl-HA was treated with $5 \mu \mathrm{g} / \mathrm{ml}$ of bovine testicular hyaluronidase (Sigma). The flHA with and without treatment of hyaluronidase were then characterized by Sepharose CL-2B chromatography mentioned below.

\section{Incubation of fl-HA with CD44/293 or 293 Cells}

CD44/293 or 293 cells $\left(5 \times 10^{6}\right)$ were plated in $10-\mathrm{cm}$ type I collagen-coated dishes and cultured for 48 hours. The cells were then cultured in the presence of $28 \mu \mathrm{g} / \mathrm{ml} \mathrm{fl-HA}$. After 48 hours of incubation, the conditioned medium was collected and cells were washed 3 times with PBS. Then, the cells were incubated in $1 \mathrm{ml}$ of $0.05 \%$ trypsin at $37^{\circ} \mathrm{C}$ for 5 minutes followed by 5 minutes centrifugation at $1300 \mathrm{~g}$. The supernatant was defined as cell surface pool. The cell pellets were washed again 3 times with PBS and then resuspended in $50 \mathrm{mM}$ Tris- $\mathrm{HCl}, \mathrm{pH} 7.4$, containing $400 \mu \mathrm{g} / \mathrm{ml}$ proteinase $\mathrm{K}$ (Sigma). The cell pellets were incubated at $37^{\circ} \mathrm{C}$ for 24 hours to solubilize the cells and release the total intracellular material. The solubilized fraction was termed intracellular pool.

\section{Characterization of fl-HA Degradation Using Size- exclusion Chromatography}

The fl-HA within the conditioned media, cell surface pools and intracellular pools was characterized by size-exclusion chromatography using a $1.6 \mathrm{~cm} \times 25 \mathrm{~cm}$ Sepharose CL-2B column equilibrated with PBS. Fractions of $2.5 \mathrm{ml}$ were collected at $0.5 \mathrm{ml} / \mathrm{minute}$ and the fluorescence (excitation, $485 \mathrm{~nm}$; emission, $535 \mathrm{~nm}$ ) was determined by an ARVO fluoroscan (PerkinElmer).

\section{CD44-HA Binding Assay}

Cells were washed and harvested with PBS, and disrupted by sonication in $50 \mathrm{mM}$ Tris- $\mathrm{HCl}, \mathrm{pH} 7.8$. The suspensions of the disrupted cells were centrifuged at $400 \mathrm{~g}$ for 5 minutes. Then, the supernatant was subjected to centrifugation at $20,000 \mathrm{~g}$ for 1 hour to yield high speed pellets. The membrane fractions were resuspended and 
adjusted to $1 \mathrm{mg} / \mathrm{ml}$ with $50 \mathrm{mM}$ Tris- $\mathrm{HCl}$, pH 7.8. A mixture of $1 \mathrm{ml}$ of the membrane fractions $(100 \mu \mathrm{g} / \mathrm{ml}$ of total protein) and $10 \mu \mathrm{l}$ of fl-HA was incubated at room temperature for various periods of time in the presence of various concentrations of $\mathrm{NaCl}$, and then centrifuged at $20,000 \mathrm{~g}$ for 10 minutes. After washing 3 times with $50 \mathrm{mM}$ Tris- $\mathrm{HCl}, \mathrm{pH} 7.8$, containing $\mathrm{NaCl}$ at a concentration equal to that used for incubation, the pellet was solubilized by $200 \mu \mathrm{l}$ of $50 \mathrm{mM}$ Tris-HCl, $\mathrm{pH} 7.4$, containing $400 \mu \mathrm{g} / \mathrm{ml}$ proteinase $\mathrm{K}$ at $37^{\circ} \mathrm{C}$ for 1 hour. The fluorescence in the lysates was measured by the ARVO fluoroscan. Nonspecific binding was determined in the presence of a large excess $(300 \mu \mathrm{g} / \mathrm{ml})$ of unlabeled hyaluronic acid.

\section{Organism, Fermentation and Isolation of F-16438s}

Taxonomic study of Gloeoporus dichrous SANK30502, and fermentation and isolation of F-16438s are reported elsewhere [32].

\section{Results and Discussion}

\section{Characterization of fl-HA}

Fluorescein-amine was conjugated to high molecular mass HA and characterized by gel filtration chromatography on a Sepharose CL-2B column. As shown in Fig. 1, the majority of fl-HA was eluted in the void volume of the column and no free fluorescein or lower molecular mass contaminants were detected. When fl-HA was treated with bovine testicular hyaluronidase, no fluorescence was detected in the void volume, indicating that the fluorescein-labeled material was highly pure HA that could be a substrate for hyaluronidase.

\section{Characterization of CD44/293 Cells}

Several studies have shown that HA is endocytosed via hyaluronic acid receptors on the cell surface, and a significant portion of endocytosed hyaluronic acid is degraded by lysosomal hyaluronidases [28, 29]. The endocytosis and degradation of HA is inhibited by antiCD44 antibody [28, 29], suggesting that CD44 has a critical role in HA turnover. We established that CD44/293 cells stably express human CD44 protein (Fig. 2A). The cells were cultured in the presence of fl-HA for 48 hours. After the conditioned medium (hereafter medium) was collected, the cells were washed with PBS and then treated with trypsin to remove pericellular-associated fl-HA (cell surface pool). The cell pellet was then subjected to exhaustive protease digestion to solubilize the cells and liberate intracellular fl-HA (intracellular pool). Fig. 2B shows the Sepharose CL-2B chromatographic profiles of fl-

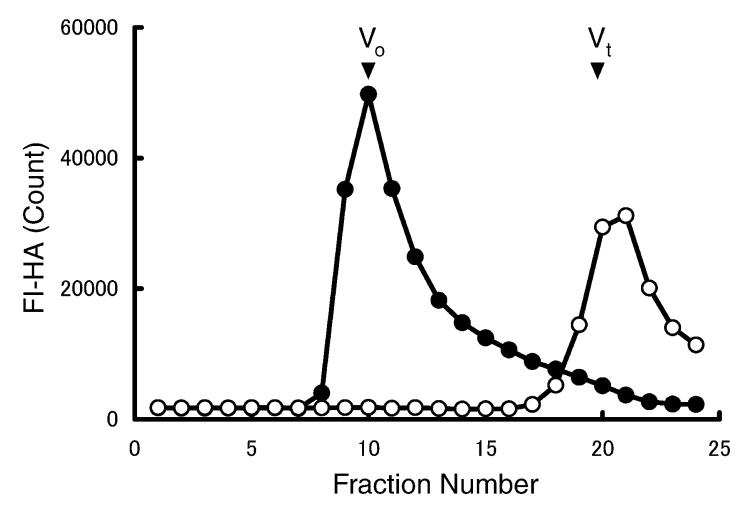

Fig. 1 Characterization of $\mathrm{fl}-\mathrm{HA}$.

Fl-HA, treated with $(O)$ or without $(\bullet)$ bovine testicular hyaluronidase was applied to a Sepharose CL-2B column and eluted with PBS. The positions of the void volume $\left(\mathrm{V}_{\mathrm{o}}\right)$ and the total volume $\left(V_{t}\right)$ are indicated.

HA in these fractions isolated from CD $44 / 293$ and 293 cells. In 293 cells, most of the added fl-HA remained in the medium, and only trace amounts of fl-HA were detected in cell surface and intracellular pools. In contrast, fl-HA was incorporated into cell surface and intracellular pools of CD44/293 cells, and the amount of high molecular fl-HA in the medium was reduced to $69.7 \%$ when compared with 293 cells. In the intracellular pool of CD44/293, degraded fl-HA with smaller molecular mass was observed in addition to the intact fl-HA that was eluted in the void volume of the Sepharose CL-2B column. Considering the fact that fl-HA was not degraded in medium or the cell surface pool of either 293 or CD44/293 cells, these results indicate that CD44, exogenously expressed on the cell surface, functioned as an HA receptor, and that the endocytosed fl-HA was degraded by lysosomal hyaluronidases in CD44/293 cells as seen in other types of cells [29].

\section{Establishment of Binding Assay Method}

The whole membrane fractions of CD44/293 cells were used for the establishment of a CD44-HA binding assay. The binding was only detected when the membranes from CD44/293 cells were used (Fig. 3A), confirming that the binding was specific to CD44. Under low ionic strength conditions, HA did not bind efficiently to simian virus 40 transfected 3T3 cells [33] which are known to express CD44 abundantly [34]. For further optimization of the receptor-binding assay, the cell membranes were incubated with fl-HA and various concentrations of $\mathrm{NaCl}$ to determine the effect of ionic strength that was considered to be a critical factor for binding. Fig. $3 \mathrm{~B}$ shows that $0.2 \mathrm{M}$ is 
(A)

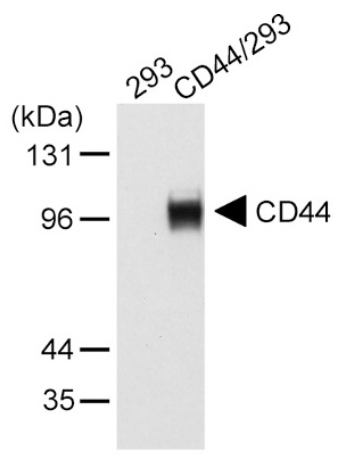

(B)

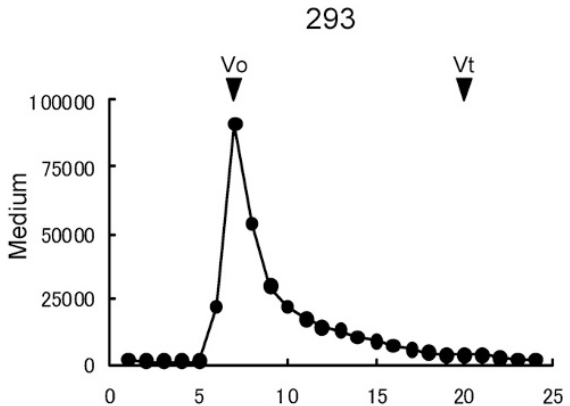

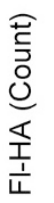
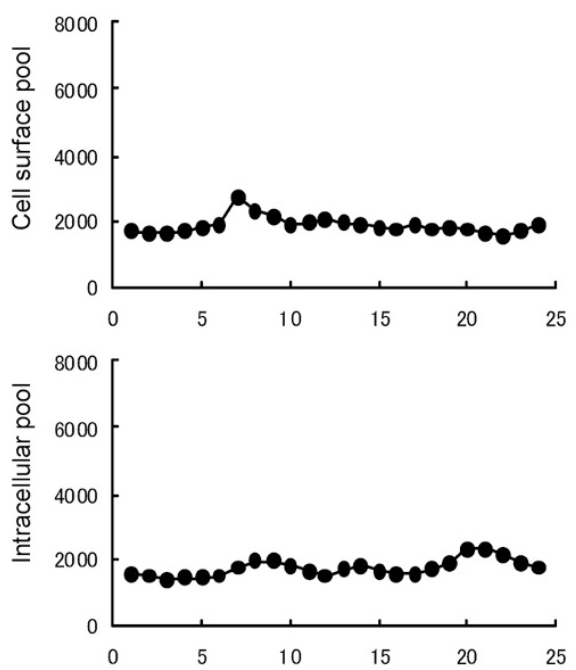

CD44/293
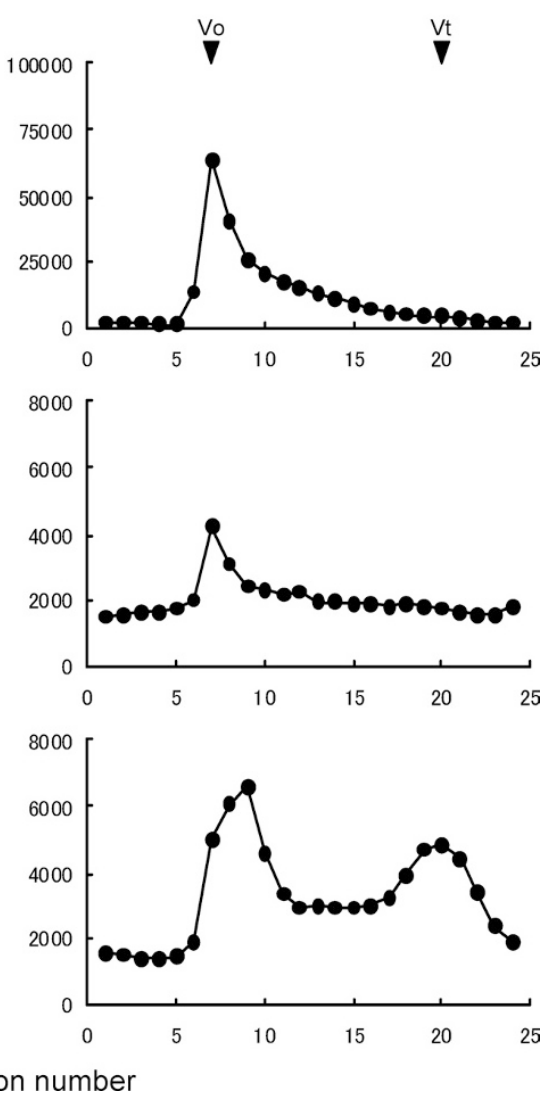

Fig. 2 Characterization of CD44/293 cells.

(A) Whole extracts of 293 and CD44/293 cells $(40 \mu \mathrm{g})$ were analyzed by western blotting with antiCD44 antibody (V6034, Biomeda). (B) Analysis of fl-HA turnover by 293 and CD44/293 cells. Cells were incubated with fl-HA at $37^{\circ} \mathrm{C}$ for 48 hours. Then, media, cell surface pools and intracellular pools were applied to a Sepharose CL-2B column and eluted with PBS. The amount of fl-HA in each fraction (2.5 ml) were determined by fluorescence as described in Materials and Methods. The positions of the void volume $\left(V_{o}\right)$ and the total volume $\left(V_{t}\right)$ are indicated.

the optimal $\mathrm{NaCl}$ concentration. When the cell membranes were incubated for various periods with fl-HA, binding increased up to 1 hour (Fig. 3C) and was retained for 2 hours incubation. At longer incubation times of more than 4 hours, however, the binding decreased. Under the standard laboratory conditions, the binding did not show temperature or $\mathrm{pH}$ dependencies; equal binding was observed at $4{ }^{\circ} \mathrm{C}$ and room temperature in the $\mathrm{pH}$ range from 7.0 to 7.8 (data not shown). Scatchard plot analysis under the optimized conditions (Fig. 3D) revealed that the values for $\mathrm{Kd}$ and $\mathrm{Bmax}$ were $0.35 \mathrm{nM}$ and $0.50 \mathrm{pmol} / \mathrm{mg}$ protein, respectively. These values had good concordance with the values obtained from binding between HA and simian virus 40-transfected $3 \mathrm{~T} 3$ cell membranes [35].

\section{Search for Inhibitors from Microbial Culture Broths}

Among 120,000 culture broths of microorganisms, fungus strain SANK 30502 was found to have inhibitory activities for CD44-HA binding. The active substances were purified after consecutive column chromatographies [32]. The chemical structures of F-16348 A, B, E, F and G are shown in Fig. 4. The dose dependent inhibition of CD44-HA binding by $\mathrm{F}-16438 \mathrm{~B}$ is shown in Fig. 5 as a representative example. The $\mathrm{IC}_{50}$ values of the inhibitory activity of F-16348 A, B, E, F and G were 10.3, 13.5, 27.3, 12.0 and $13.0 \mu \mathrm{M}$, respectively (Table 1). F-16438 A, B, E and F were found to be new found structures whereas F-16438G was a previously identified phospholipase $\mathrm{C}$ inhibitor [36]. The compounds did not show any cytotoxicity to HEK293 cells up to $100 \mu \mathrm{g} / \mathrm{ml}$. These compounds are the first reported low-molecular weight inhibitors of CD44-HA binding; this discovery well demonstrated the utility of the new CD44-HA binding assay. It is expected that this series of compounds will serve as new chemical probes of HA-CD44 interactions and functions. 
(A)

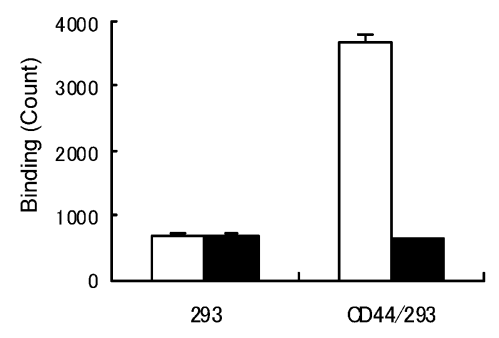

(C)

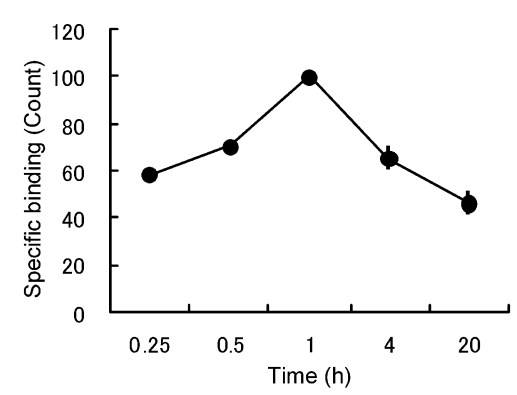

(B)

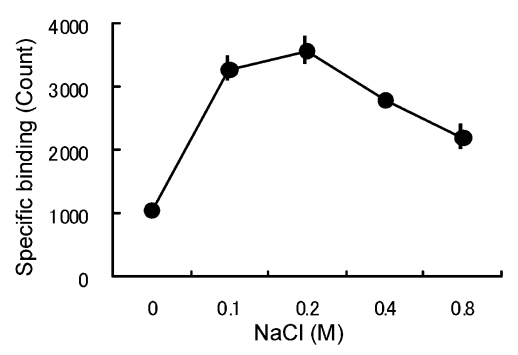

(D)

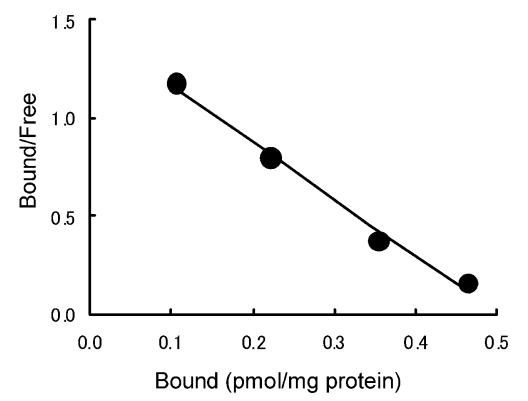

Fig. 3 Binding of fl-HA to CD44/293 cell membranes.

(A) Specificity of fl-HA binding to CD44. The cell membranes prepared from 293 or CD44/293 cells were incubated with fl-HA (3 $\mu \mathrm{g} / \mathrm{ml}$ ) at room temperature for 1 hour in the presence of $0.2 \mathrm{M} \mathrm{NaCl}$. Following incubation, the cell membranes were washed three times and digested with proteinase $\mathrm{K}$. The fluorescence in the sample was measured using an ARVO fluoroscan. Open columns and closed columns indicate total binding and nonspecific binding, respectively. Bars indicate SD. (B) Effect of $\mathrm{NaCl}$ concentration on binding of fl-HA to CD44. The cell membranes were incubated with $\mathrm{fl}-\mathrm{HA}(3 \mu \mathrm{g} / \mathrm{ml})$ in the presence of various concentrations of $\mathrm{NaCl}$ as indicated. (C) Timedependency of fl-HA binding. The cell membranes were incubated with fl-HA $(3 \mu \mathrm{g} / \mathrm{ml})$ for $0.25 \sim 20$ hours. (D) Scatchard plot of fl-HA binding. The cell membranes were incubated with various concentrations of $\mathrm{fl}-\mathrm{HA}(0 \sim 10 \mu \mathrm{g} / \mathrm{ml})$ under optimized conditions.

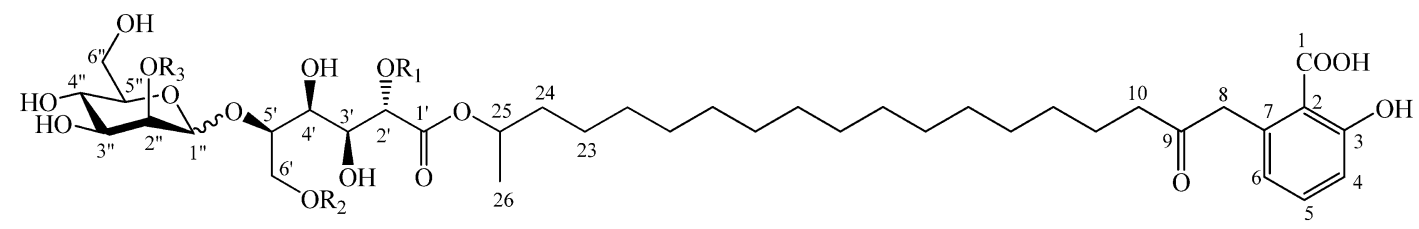

F-16438 A (1) $\quad \mathrm{R}_{1}=\mathrm{R}_{2}=\mathrm{R}_{3}=\mathrm{H}$

F-16438 B (2) $\quad \mathrm{R}_{1}=\mathrm{R}_{2}=\mathrm{H}, \mathrm{R}_{3}=\mathrm{COCH}_{3}$

F-16438 E (3) $\quad \mathrm{R}_{1}=\mathrm{COCH}_{3}, \mathrm{R}_{2}=\mathrm{H}, \mathrm{R}_{3}=\mathrm{COCH}_{3}$

F-16438 F (4) $\quad \mathrm{R}_{1}=\mathrm{COCH}_{3}, \mathrm{R}_{2}=\mathrm{COCH}_{2} \mathrm{COOH}, \mathrm{R}_{3}=\mathrm{COCH}_{3}$

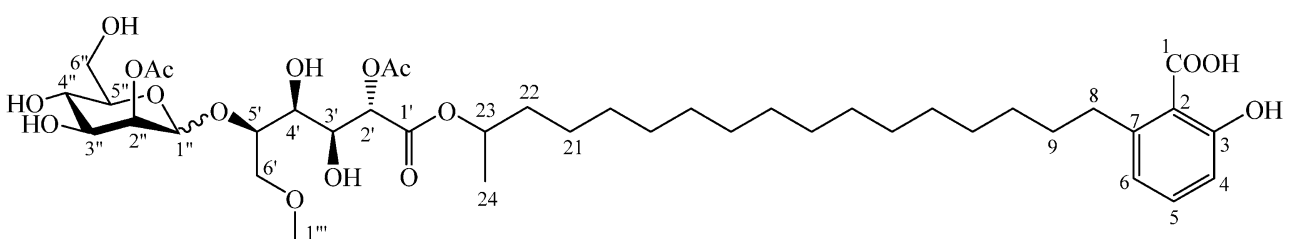<smiles>CC(=O)[CH+]C(=O)O</smiles>

F-16438 G (5)

Fig. 4 Structures of F-16438 A, B, E, F and G. 


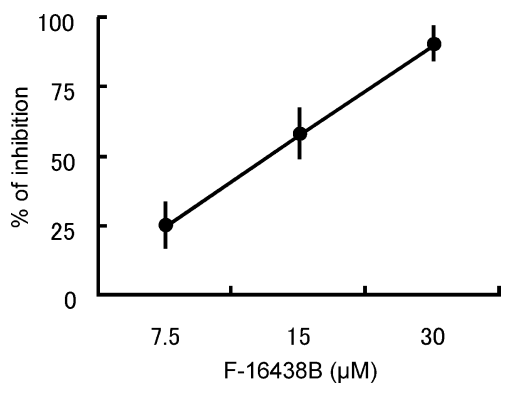

Fig. 5 Dose dependent inhibition of CD44-HA binding by F-16438 B.

The cell membranes were incubated with fl-HA ( $3 \mu \mathrm{g} / \mathrm{ml})$ under optimized conditions in the presence of various concentrations of $\mathrm{F}-16438 \mathrm{~B}$ as indicated.

\section{References}

1. Toole BP. Proteoglycans and hyaluronan in morphogenesis and differentiation. In Cell biology of extracellular matrix. Ed., ED. Hay, pp. 61-92, Plenum Press, New York (1991)

2. Toole BP. Hyaluronan in morphogenesis. Semin Cell Dev Biol 12: 79-87 (2001)

3. Longaker MT, Chiu ES, Adzick NS, Stern M, Harrison MR, Stern R. Studies in fetal wound healing. V. A prolonged presence of hyaluronic acid characterizes fetal wound fluid. Ann Surg 213: 292-296 (1991)

4. Weigel PH, Fuller GM, LeBoeuf RD. A model for the role of hyaluronic acid and fibrin in the early events during the inflammatory response and wound healing. J Theor Biol 119: 219-234 (1986)

5. de la Motte CA, Hascall VC, Drazba J, Bandyopadhyay SK. Strong SA. Mononuclear leukocytes bind to specific hyaluronan structures on colon mucosal smooth muscle cells treated with polyinosinic acid: polycytidylic acid: interalpha-trypsin inhibitor is crucial to structure and function. Am J Pathol 163: 121-133 (2003)

6. Majors AK, Austin RC, de la Motte CA, Pyeritz RE, Hascall VC, Kessler SP, Sen G, Strong SA. Endoplasmic reticulum stress induces hyaluronan deposition and leukocyte adhesion. J Biol Chem 278: 47223-47231 (2003)

7. Toole BP. Hyaluronan promotes the malignant phenotype. Glycobiology 12: 37-42 (2002)

8. Toole BP, Hascall VC. Hyaluronan and tumor growth. Am J Pathol 161: 745-747 (2002)

9. Ascher B, Cerceau M, Baspeyras M, Rossi B. Soft tissue filling with hyaluronic acid. Ann Chir Plast Esthet 49: 465-485 (2004)

10. Abatangelo G, O'Regan M. Hyaluronan: biological role and function in articular joints. Eur J Rheumatol Inflamm 15: 9-16 (1995)

11. Dahl LB, Dahl IMS, Engström-Laurent A, Granath K. Concentration and molecular weight of sodium hyaluronate in synovial fluid from patients with rheumatoid arthritis and
Table 1 Inhibition of binding between CD44 and HA by F-16438s

\begin{tabular}{cc}
\hline Compound & $\mathrm{IC}_{50}(\mu \mathrm{M})$ \\
\hline F-16438 A & 10.3 \\
F-16438 B & 13.5 \\
F-16438 E & 27.3 \\
F-16438 F & 12.0 \\
F-16438 G & 13.0 \\
\hline
\end{tabular}

other arthropathies. Ann Rheum Dis 44: 817-822 (1985)

12. Ghosh P. The role of hyaluronic acid (hyaluronan) in health and disease: interactions with cells, cartilage and components of the synovial fluid. Clin Exp Rheumatol 12: 75-82 (1994)

13. Lesley J, Hyman R, Kincade PW. CD44 and its interaction with extracellular matrix. Adv Immunol 54: 271-335 (1993)

14. Picker LJ, Nakache M, Butcher EC. Monoclonal antibodies to human lymphocyte homing receptors define a novel class of adhesion molecules on diverse cell types. J Cell Biol 109: 927-937 (1989)

15. Bourguignon LY, Lokeshwar VB, He J, Chen X, Bourguignon GJ. A CD44-like endothelial cell transmembrane glycoprotein (GP116) interacts with extracellular matrix and ankyrin. Mol Cell Biol 12: 4464-4471 (1992)

16. Zhu D, Bourguignon LY. Overexpression of CD44 in p185(neu)-transfected NIH3T3 cells promotes an upregulation of hyaluronic acid-mediated membranecytoskeleton interaction and cell adhesion. Oncogene 12: 2309-2314 (1996)

17. Brown TA, Bouchard T, St John T, Wayner E, Carter WG. Human keratinocytes express a new CD44 core protein $(\mathrm{CD} 44 \mathrm{E})$ as a heparan-sulfate intrinsic membrane proteoglycan with additional exons. J Cell Biol 113: 207-221 (1991)

18. Grover J, Roughley PJ. Expression of cell-surface proteoglycan mRNA by human articular chondrocytes. Biochem J 309: 963-968 (1995)

19. Aruffo A, Stamenkovic I, Melnick M, Underhill CB, Seed B. CD44 is the principal cell surface receptor for hyaluronate. Cell 61: 1303-1313 (1990)

20. Miyake K, Underhill CB, Lesley J, Kincade PW. Hyaluronate can function as a cell adhesion molecule and CD44 participates in hyaluronate recognition. J Exp Med 172: 69-75 (1990)

21. Stamenkovic I, Aruffo A, Amiot M, Seed B. The hematopoietic and epithelial forms of CD44 are distinct polypeptides with different adhesion potentials for hyaluronate bearing cells. EMBO J 10: 343-348 (1991)

22. Shimizu Y, Van Seventer GA, Siraganian R, Wahl L, Shaw $\mathrm{S}$. Dual role of the CD44 molecule in T cell adhesion and activation. J Immunol 143: 2457-2463 (1989) 
23. Lesley J, Howes N, Perschl A, Hyman R. Hyaluronan binding function of CD44 is transiently activated on T cells during an in vivo immune response. J Exp Med 180: 383-387 (1994)

24. Gunthert U, Hofmann M, Rudy W, Reber S, Zoller M, Haussmann I, Matzku S, Wenzel A, Ponta H, Herrlich P. A new variant of glycoprotein CD44 confers metastatic potential to rat carcinoma cells. Cell 65: 13-24 (1991)

25. Sy MS, Guo YJ, Stamenkovic I. Distinct effects of two CD44 isoforms on tumor growth in vivo. J Exp Med 174: 859-866 (1991)

26. Udabage L, Brownlee GR, Nilsson SK, Brown TJ. The overexpression of HAS2, Hyal-2 and CD44 is implicated in the invasiveness of breast cancer. Exp Cell Res 310: 205-217 (2005)

27. Chow G, Knudson CB, Homandberg G, Knudson W. Increased expression of CD44 in bovine articular chondrocytes by catabolic cellular mediators. J Biol Chem 270: 27734-27741 (1995)

28. Culty M, Nguyen HA, Underhill CB. The hyaluronan receptor (CD44) participates in the uptake and degradation of hyaluronan. J Cell Biol 116: 1055-1062 (1992)

29. Hua Q, Knudson CB, Knudson W. Internalization of hyaluronan by chondrocytes occurs via receptor-mediated endocytosis. J Cell Sci 106: 365-375 (1993)

30. Tammi R, Rilla K, Pienimaki JP, MacCallum DK, Hogg M, Luukkonen M, Hascall VC, Tammi M. Hyaluronan enters keratinocytes by a novel endocytic route for catabolism. J Biol Chem 276: 35111-35122 (2001)

31. Hirota-Takahara Y, Harada H, Tanaka I, Nakata T, Nakajima M, Takahashi M. F-16438s, novel binding inhibitors of and hyaluronic acid CD44. II. Producing organism, fermentation, isolation, physico-chemical properties and structural elucidation. J Antibiot 59: 770-776

32. de Belder AN, Wik KO. Preparation and properties of fluorescein-labelled hyaluronate. Carbohydr Res 44: 251-257 (1975)

33. Underhill CB, Toole BP. Physical characteristics of hyaluronate binding to the surface of simian virus 40transformed 3T3 cells. J Biol Chem 255: 4544-4549 (1980)

34. Underhill CB, Green SJ, Comoglio PM, Tarone G. The hyaluronate receptor is identical to a glycoprotein of Mr 85,000 (gp85) as shown by a monoclonal antibody that interferes with binding activity. J Biol Chem 262: 13142-13146 (1987)

35. Underhill CB, Chi-Rosso G, Toole BP. Effects of detergent solubilization on the hyaluronate-binding protein from membranes of simian virus 40-transformed 3T3 cells. J Biol Chem 258: 8086-8091 (1983)

36. Weber W, Schu P, Anke T, Velten R, Steglich W. Caloporoside, a new inhibitor of phospholipases $\mathrm{C}$ from Caloporus dichrous (Fr.) Ryv. J Antibiot 47: 1188-1194 (1994) 